\title{
Post-harvest seed-borne diseases associated with the seeds of three varieties of groundnuts, (Arachis hypogaea L) Nwakara, Kaki, and Campalla
}

\author{
Ibiam, O. F. A and Egwu, B.N \\ ${ }^{1}$ Department of Applied Biology, Ebonyi State University Abakaliki. Ebonyi State. Nigeria . \\ Corresponding Author's E-mail: drakanuibiamir@.com
}

\begin{abstract}
Fresh, cooked and fried seeds of three varieties of groundnuts (Arachis hypogaea L) Nwakara, Kaki and Campalla, were screened to determine the post-harvest seed-borne fungi associated with them. Results obtained showed that no fungi was associated with fresh seeds of Nwakara and kaki varieties, whereas Aspergillus niger, A. flavus, A. terreus, A. culmorum, A. fumigatus, $A$. nidulans, A. tamarii, Fusarium moniliforme, Mucor rouxii, Penicillium spp., Cladosporium spp., and Aureobasidium pullulans associated with fried and cooked seeds of the three varieties, Nwakara, Kaki, and Campalla. More fungi were associated with the old varieties than the fresh ones.
\end{abstract}

Keywords: post harvest, diseases, groundnuts, seed borne, seeds

\section{INTRODUCTION}

Groundnut (Arachis hypogaea L.) is an important leguminous agricultural plant in Nigeria. It is cultivated for its seeds as a source of oil, for direct human consumption as a protein and Vitamins A, B and some members of $B_{2}$ group supplement in humans and animal food (Purseglove, 1979). The biproduct, derived from the seeds after extraction of the oil could serve as an essential ingredient of poultry and animal feed; and could be made into groundnut cake popularly called 'kwulikwuli' in the Hausa language, and for manufacturing artificial fibre and treatment of soil nematode. The shell could be used as fuel for manufacturing coarse boards, and cork substitute. The kernels could be eaten raw, roasted or sweetened. The oil could also be used for soap making, manufacturing of cosmetics and lubricants etc.

As reported by Nwokolo, (1996), peanuts are a good source of niacin, and thus contribute to brain health and blood flow, associated with reduced cardiovascular disease and reduced cancer risks; accelerate the growth of male and female hormones; are a source of co-enzyme along with oil fish, beef, soybean and spinach; and could course allergies.

The crop is popularly grown in the Northern part of Nigeria,(Kano and Bornu States ) and also in the Eastern Parts (Enugu and Ebonyi States). This important crop is attacked by a number of pathogenic fungi of economic importance. Sullivan(1984), reported that groundnut seeds are highly susceptible to diseases, as they serve as a source of stored nutrients for fungi such as Rhizopus spp., Penicillium spp., Aspergillus niger, and $A$. flavus. This is evident in the work of Woodroof (1984), who observed that groundnut seed samples that are not removed from their shells are not subject to attack by microorganisms and insects as those not removed from their shells. This report was corroborated by the work of Ibrahim et al, (1986), which stated that if grains are dry harvested, they would not be subject to great damage by microorganisms, as these organisms require certain amount of moisture to grow and multiply.

McDonald (1970), reported that Fusarium spp., Aspergillus spp. and Penicillium spp., were the most abundant fungi encountered in groundnut seeds tested before harvest, while Macrophomina phaseolina and Fusarium spp., were abundant on seeds of over-mature and window dried fruits. He further stated that the most important abundant environmental factor that influences the growth of endo-giocarpic micro-flora during and after drying and curing in pods and kernel is moisture, and that apart from moisture content of the seeds, several environmental factors, relative humidity and temperature within storage facilities, influence the extent to which fungal growth and aflatoxin contamination occurs. Diener et al, (1986), stated that if groundnut seed moisture content exceeded 9 $\%$ at equilibrium humidity of 80 and $90 \%$, the 
chances of invasion by Aspergillus flavus increased drastically. Umechuruba (1986), Isolated Macrophomina phaseolina, Penicillium spp., Fusarium equiseti, F. solani, F. moniliforme var. subglutinans, $F$. sambicum, $F$. semitectum, $F$. moniliforme, Colletorichum dematium, Aspergillus niger and $A$ flavus from thirteen unshelled groundnut samples from Nigeria. Aspergillus niger, Fusarium, Penicilium and Cladosporium are the predominant fungal genera associated with grains in storage, and aflatoxins of all mycotoxin is of utmost concern (CAST, 2003). This is due to their carcinogens and immunosuppressive effects in both humans and domestic animals (Turner et al., 2003).

Considering the quantity of groundnut that arrive at the markets from various villages around the Abakaliki Metropolis, and that should also consumed by the Metropolitan inhabitants in their various forms of preparations, as well as the heath implications, we decided to investigate the seed-borne fungi associated with the seeds of the varieties sold in their various forms, with a view to providing some current data that will be useful to human pathologists.

\section{MATERIALS AND METHODS.}

Materials: Groundnut seeds fried with their pericarp (shell), and those fried but with their pericarp removed; those cooked with their shells and those cooked and their shells removed, shelled and unshelled fresh ones of the three varieties, Nwakara, Kaki and Campalla, were screened to determine the seed-borne fungi associated with them. These seeds were collected in July, 2010 from markets (Abakpa and Npirikpiri) in Abakaliki Metropolis.

Methods: Standard blotter method as described by the International Seed Testing Association (ISTA 1976), was used for the isolation of the seed-borne fungi associated with the groundnut seed samples. The seed samples were first sterilized in $4 \%$ sodium hypochlorite (Chlorox) for five minutes and rinsed in several changes of sterile distilled water. The sterilized seed samples in their various forms according to their varieties, were then inoculated on three moistened $9.0 \mathrm{~cm}$ filter papers in $9.0 \mathrm{~cm}$ Oswald Petri-dishes. Five seeds were arranged at the periphery of the plate, four at the middle, and one at the centre. A total of four hundred seed samples per preparation, per variety, was used.

The control for each sample per preparation, per variety was not treated with sodium hypochlorite, but was only washed with distilled water. Both the control and the treatment were incubated in the dark at a temperature of $25 \pm 2{ }^{\circ} \mathrm{C}$ in the incubator. Identification of the fungi was made based on their habit character, following the method of Burnett and Hunter (2000). Where the identification of any fungus was in doubt, spore suspensions of it were made on the slide and viewed under the microscope at $\times 20$. magnification

Statistical Analysis: Multivariate analysis and Duncan's multiple range was used for the statistical analysis of the generated data.

\section{RESULTS AND DISCUSSION}

Results of the incidence of the seed-borne fungi associated with the seeds of three different varieties of groundnuts Nwakara, kaki and Campalla, (Table I) showed that Aspergillus flavus, A. niger, A. tamarii, $A$. terreus, A. fumigatus, A. culmorum, A. nidulans, Fusarium moniliforme, Cladosporium spp., Penicillium citrinum, $P$. chrisogenum, Areobasidium pullulans and Mucor rouxii were associated with seeds of the three varieties in their various preparations. Aspergillus flavus was the most preponderant fungus. More fungi were associated with the old varieties than the fresh ones. The result of the statistical analysis (Table 1) showed that those with the same subscript vertically, indicate that they are not significantly different, while those with different subscripts indicate that they are significantly different; all at $\mathrm{P}<0.05$.

This result corroborates the report of Sullivan (1984) that groundnut seeds are highly susceptible to disease, as they act as a source of stored nutrients for fungi such as Rhizopus spp., Penicillium spp., Aspergillus niger and A. flavus. Umechuruba (1986), also isolated Macrophomina phaseolina, Penicillium spp , Fusarium equiseti, $F$. solani, $F$ moniliforme var. subglutinans, $F$. sambicum, $F$. semitectum, $F$. moniliforme, Colletotrichum dematium, Aspergillus niger and $A$. flavus from thirteen unshelled groundnut samples from Nigeria.

Apart from the unshelled fresh groundnut seeds of the varieties Nwakara and kaki, the unshelled roasted seeds of the three varieties were not affected by any fungal attack. This could be as a result of the thermal effect of roasting the unshelled seeds of the varieties, as heat must have killed them. This agrees with Woodroof (1984), who reported that unshelled seeds of groundnut seeds are not subject to attack by microorganisms. However, this depends on the varieties involved, as seeds of the varieties, Kaki and Nwakara were affected by many fungi as shown in the Table. 
Agric. Biol. J. N. Am., 2011, 2(4): 598-602

Table 1 Fungi isolated from different preparations of seeds of groundnuts from markets in Abkaliki metropolis

\begin{tabular}{|c|c|c|c|c|c|c|c|c|c|c|c|c|}
\hline \multirow[t]{2}{*}{ Variety } & \multicolumn{11}{|c|}{ POST-HARVEST FUNGI ISOLATED } & \multirow[b]{2}{*}{$\begin{array}{l}\text { Cladosp } \\
\text { orium } \\
\text { spp }\end{array}$} \\
\hline & $\begin{array}{l}\text { Aspergillus } \\
\text { flavus }\end{array}$ & $\begin{array}{l}\text { Aspergillus } \\
\text { niger }\end{array}$ & $\begin{array}{l}\text { Aspergillus } \\
\text { tamari }\end{array}$ & $\begin{array}{l}\text { Aspergill } \\
\text { us } \\
\text { terreus }\end{array}$ & $\begin{array}{l}\text { A } \\
\text { spergilllu } \\
\text { s } \\
\text { nidulans }\end{array}$ & $\begin{array}{l}\text { Aspergillus } \\
\text { fumigatus }\end{array}$ & $\begin{array}{l}\text { Aspergill } \\
\text { us } \\
\text { culmoru } \\
m\end{array}$ & $\begin{array}{l}\text { Fusarium } \\
\text { moniliforme }\end{array}$ & $\begin{array}{l}\text { Aureoba } \\
\text { sidium } \\
\text { pullulans }\end{array}$ & $\begin{array}{l}\text { Penicillium } \\
\text { chrysogen } \\
\text { um }\end{array}$ & $\begin{array}{l}\text { Penicilliu } \\
m . \\
\text { citrinum }\end{array}$ & \\
\hline \multicolumn{13}{|c|}{ OLD VARIETIES } \\
\hline \multicolumn{13}{|c|}{ FRIED WITH PERICARP } \\
\hline Campalla & $29 \pm 1.2$ & $25.6 \pm 2.5^{\dagger}$ & $00 \pm 00$ & ${ }_{c}^{12.7 \pm 1.5}$ & ${ }_{c}^{11.3 \pm 1.5}$ & $6.0 \pm 1.0^{c}$ & $00 \pm 00$ & $14.7 \pm 2.5^{\mathrm{e}}$ & $00 \pm 00$ & $00 \pm 00$ & $14 \pm 2.0^{b b}$ & $00 \pm 00$ \\
\hline Nwakara & $76.3 \pm 3.5^{1}$ & $08 \pm 1.0^{b}$ & $00 \pm 00$ & $9.3 \pm 1.5^{a}$ & $5.7 \pm 1.5^{a}$ & $4.0 \pm 1.0^{b}$ & $00 \pm 00$ & $9.3 \pm 1.5^{c}$ & $00 \pm 00$ & $00 \pm 00$ & $14.7 \pm 2.1^{b}$ & $00 \pm 00$ \\
\hline Kaki & $28 \pm 3.0^{\mathrm{e}}$ & $09 \pm 1.0^{c}$ & $\pm 2.0^{\mathrm{d}}$ & $9.3 \pm 1.5^{b}$ & $5.7 \pm 1.2^{\mathrm{a}}$ & $13 \pm 1.0^{\dagger}$ & $00 \pm 00$ & $14.3 \pm 1.5^{\mathrm{e}}$ & $00 \pm 00$ & $00 \pm 00$ & $12.7 \pm 2.1^{\mathrm{a}}$ & $00 \pm 00$ \\
\hline \multicolumn{13}{|c|}{ UNFRIED } \\
\hline Campalla & $37.3 \pm 2.5^{9}$ & $244.7 \pm 2.5^{9}$ & $00 \pm 00$ & $13 \pm 1.7^{c}$ & $20 \pm 2.0^{\mathrm{e}}$ & $12 \pm 2.0^{\mathrm{e}}$ & $00 \pm 00$ & $22 \pm 2.0^{g}$ & $00 \pm 00$ & $00 \pm 00$ & $16.3 \pm 1.5^{c}$ & $15.3 \pm 1.5$ \\
\hline Nwakara & $86.3 \pm 9.1^{1}$ & $13.7 \pm 1.5^{\mathrm{d}}$ & $00 \pm 00$ & $\frac{16.7 \pm 1.5}{d}$ & $15 \pm 2.0^{d}$ & $6.7 \pm 0.6^{c}$ & $00 \pm 00$ & $17 \pm 1.0^{\dagger}$ & $00 \pm 00$ & $00 \pm 00$ & $25.3 \pm 0.6^{d}$ & ${ }_{c}^{28.3 \pm 0.6}$ \\
\hline Kaki & $24 \pm 2.0^{\mathrm{e}}$ & $19.7 \pm 2.1^{\mathrm{e}}$ & $14 \pm 1.5^{\mathrm{e}}$ & $\frac{13.3 \pm 1.0}{d}$ & ${ }_{\mathrm{e}}^{19.3 \pm 1.5}$ & $21.3 \pm 1.5^{n}$ & $00 \pm 00$ & $18.7 \pm 3.1^{\dagger}$ & $00 \pm 00$ & $00 \pm 00$ & $13.0 \pm 1.0^{a}$ & $\frac{13.3 \pm 1.5}{a}$ \\
\hline \multicolumn{13}{|c|}{ DRY AND UNSHELLED } \\
\hline Campalla & $21.7 \pm 0.6^{\mathrm{d}}$ & $11 \pm 1.0^{\mathrm{C}}$ & $00 \pm 00$ & ${ }^{\mathrm{e}} 23 \pm 2.0$ & $00 \pm 000$ & ${ }^{g} 16.3 \pm 1.5$ & $00 \pm 00$ & $7.0 \pm 1.0^{b}$ & $00 \pm 00$ & $00 \pm 00$ & $00 \pm 00$ & $00 \pm 00$ \\
\hline Nwakara & $43.3 \pm 0.6^{h}$ & $09.3 \pm 1.5^{b}$ & $00 \pm 00$ & ${ }^{b} 9.7 \pm 2.1$ & $00 \pm 00$ & ${ }^{e} 12 \pm 1.0$ & $00 \pm 00$ & $11 \pm 1.0^{c}$ & $00 \pm 00$ & $00 \pm 00$ & $00 \pm 00$ & $00 \pm 00$ \\
\hline Kaki & $23.3 \pm 1.5^{\mathrm{d}}$ & $13.3 \pm 1.5^{\mathrm{d}}$ & $02.3 \pm 1.5^{a}$ & $26 \pm 1.7$ & $7.7 \pm 1.5^{b}$ & ${ }^{d} 8.3 \pm 1.5$ & $00 \pm 00$ & $12.7 \pm 0.6^{d}$ & $00 \pm 00$ & $00 \pm 00$ & $00 \pm 00$ & $00 \pm 00$ \\
\hline \multicolumn{13}{|c|}{ NEW VARIETIES } \\
\hline \multicolumn{13}{|c|}{ UNSHELLED AND COOKED } \\
\hline Campalla & $14.3 \pm 2.1^{c}$ & $00 \pm 00$ & $7 \pm 0.6^{b}$. & ${ }^{a} 6.0 \pm 1.0$ & $00 \pm 00$ & $11 \pm 1.0^{\mathrm{e}}$ & $00 \pm 00$ & $00 \pm 00$ & $6.0 \pm 1.0^{a}$ & $00 \pm 00$ & $8.0 \pm 7.0^{\text {a a }}$ & $00 \pm 00$ \\
\hline Nwakara & $47.3 \pm 1.5^{h}$ & $00 \pm 00$ & $5.7 \pm 0.6^{b}$ & $00 \pm 00$ & $00 \pm 00$ & $15.7 \pm 1.2^{\mathrm{g}}$ & $00 \pm 00$ & $00 \pm 00$ & $5.3 \pm 0.6^{a}$ & $00 \pm 00$ & $12.3 \pm 0.6^{b}$ & $00 \pm 00$ \\
\hline Kaki & $16.3 \pm 1.5^{c}$ & $00 \pm 00$ & $08.0 \pm 1.0^{\mathrm{C}}$ & $00 \pm 00$ & $00 \pm 00$ & $2.3 \pm 0.6^{a}$ & $00 \pm 00$ & $00 \pm 00$ & $20 \pm 1.0^{c}$ & $00 \pm 00$ & $33.0 \pm 16.5^{\mathrm{e}}$ & $00 \pm 00$ \\
\hline \multicolumn{13}{|c|}{ UNSHELLED AND UNCOOKED } \\
\hline Campalla & $00 \pm 00$ & $5.3 \pm 0.6^{a}$ & $00 \pm 00$ & ${ }^{\mathrm{b}} 10 \pm 1.0$ & $00 \pm 00$ & $00 \pm 00$ & $7.0 \pm 1.0^{a}$ & $4.3 \pm 0.6^{a}$ & $12.3 \pm 1.5$ & $00 \pm 00$ & $5.3 \pm 06^{c}$ & $00 \pm 00$ \\
\hline Nwaka & $00 \pm 00$ & $00 \pm 00$ & $00 \pm 00$ & $00 \pm 00$ & $00 \pm 00$ & $00 \pm 00$ & $00 \pm 00$ & $00 \pm 00$ & $00 \pm 00$ & $00 \pm 00$ & $00 \pm 00$ & $00 \pm 00$ \\
\hline Kaki & $00 \pm 00$ & $00 \pm 00$ & $00 \pm 00$ & $00 \pm 00$ & $00 \pm 00$ & $00 \pm 00$ & $00 \pm \pm 00$ & $00 \pm 00$ & $00 \pm 00$ & $00 \pm 00$ & $00 \pm 00$ & $00 \pm 00$ \\
\hline \multicolumn{13}{|c|}{ UNSHELLED AND ROASTED } \\
\hline Campalla & $04.3 \pm 0.6^{a}$ & $00 \pm 00$ & $00 \pm 00$ & $00 \pm 00$ & $00 \pm 00$ & $00 \pm 00$ & $00 \pm 00$ & $3.3 \pm 0.6^{a}$ & $00 \pm 00$ & $9.0 \pm 1.0^{c}$ & $00 \pm 00$ & $00 \pm 00$ \\
\hline Nwakara & $01.3 \pm 0.6^{a}$ & $00 \pm 00$ & $00 \pm 00$ & $00 \pm 00$ & $00 \pm 00$ & $00 \pm 00$ & $00 \pm 00$ & $3.7 \pm 1.2^{a}$ & $00 \pm 00$ & $2.3 \pm 0.6^{a}$ & $00 \pm 00$ & $00 \pm 00$ \\
\hline Kaki & $09 \pm 1.0^{b}$ & $00 \pm 00$ & $00 \pm 00$ & $00 \pm 00$ & $00 \pm 00$ & $00 \pm 00$ & $00 \pm 00$ & $3.3 \pm 0.6^{a}$ & $00 \pm 00$ & $3.3 \pm 0.6^{b}$ & $00 \pm 00$ & $00 \pm 00$ \\
\hline & & & & & & & & & & & & \\
\hline
\end{tabular}


Fungal development on groundnuts during or after harvest has been reported to be hazardous, particularly, when Aspergillus flavus, which produces aflatoxin which is carcinogenic is involved, as reported by Shewfelt et al, (1977). Moisture could be one of the factors that encouraged growth on the shelled and unshelled cooked groundnut and informs why shelled groundnut seeds were attacked by the fungi, as they picked up moisture from the atmosphere, which provided the conditions necessary for fungal spores in the air to get attached to the surface of the seeds. The presence of these fungi on both cooked and fried groundnut seeds ,despite the fact that they were not attacked when they were fresh, pose great danger to human health. Aspergillus flavus produce an important metabolite, Aflatoxin (a mycotoxin), which has been shown to be carcinogenic to man, domestic and other laboratory animals (Aletor, 1990). Aspergillus species like $A$. niger caused some "fungal ball", a situation where the fungus actively proliferates in the human lung forming a ball, according to TBMIC (2006). OSHA (2005) also reported that Aureobasidium pullulans and Cladosporium spp., Aspergillus flavus, A. niger, A. nidulans, $A$. ochraceous etc., being allergens and irritants, could also cause hypersensitivity, pneumatitis and dermatitis. Cladosporium spp. are also agents of skin lesions ,keratitis, sinusitis, asthma and pulmonary infections, and chronic exposure may lead to pulmonary emphysema; Penicillium also causes asthma, hypersensitivity, pneumatitis, alveolitis and was reported to produce ochratoxin A, which is nephrotoxic and carcinogenic. It also produces other mycotoxins which could cause a number of diseases like sore throat, headache, nose bleeding, fatigue, diarrhea, dermatitis and immunosuppressions (TBMIC, 2006). They further reported that Fusarium spp. are frequently involved with eye, skin and nail infections, and that more severe cases could cause haemorrhagic syndrome (alimeatary toxic aleukamia), dermatitis and extensive internal bleeding. Fusaria are reputed to be emerging causes of opportunistic mycosis.Several of these species of fungi isolated could also produce Trichothecene toxins, which was reported by TBMIC (2006) to target circulatory, skin, and nervous system, and are capable of causing severe damage to the entire digestive system if ingested in large amounts, causing rapid death due to internal haemorrage and infant pulmonary hemosiderosis. They also reported that vomitoxin, for instance, has been associated with outbreaks of acute gastrointestinal illness in humans, as well as
Zearalenone, a Mycotoxin, all of these being produced by Fusarium spp. .Mucor is a dangerous mold that could adversely affect the respiratory system, causing Zygomycosis.(OSHA, 2005).

If all the above mentioned diseases are caused by these fungi as shown above, and they were isolated from groundnut seeds, which are constantly eaten by the generality of people in the state in their susceptible forms, then there is danger because those people who eat them in excess stand the danger of suffering some of the illnesses outlined above. It could also pose great danger to poultry farming since it forms an ingredient of some feed formulations for the poultry. It becomes necessary that more studies should be carried out on the effect of these groundnut seeds on those who eat it moderately or heavily, and those who do not eat it altogether for a period of time, with a view to determining the quantity that should be eaten at a given time. However, we recommend eating of fresh ground nuts which are not infected by any seedborne fungi.

\section{REFERENCES}

Aletor,V.A. (1990). Aflatoxin contamination in some Nigerian feeds and feeding Stuffs highlights of some nutritional, physiological and economic implications .Food Chemistry 37:145-153.

Burnett, H. L and Hunter B. B.(2000).Illustrated Genera of Imperfect Fungi. McGraw Hill, New York, 218 pp.

Council for Agricultural Science and Technology (CAST) (2003) Mycotoxins: Risks to plants, animals and human systems.CAST. Ames. Iowa U.S.A

Diener, U.L and Cole, R.J. (1982). Aflatoxins and other Mycotoxinsin peanuts.In: Pea nut Science and Technology.Pattee, H. E and Young, C. T(eds) pp486519. Yakum, Texas U.S.A. American Peanut Research and Educational Society.

Hell, K., Cardwell, K.F and Poehling, H.M. (2003). Distribution of fungal species and aflatoxin contamination in stored maize in four agroecological zones in Benin. West Africa Journal of Phytopathology151:690-698.

Ibrahim, H.E and Ebo, K. C. (1986) Mycoflora of stored crops from six northern States in Nigeria. National Stored Products Research Institute technical No.1:26.

International Seed Testing Association (ISTA) (1976).Seed Science and Technology. 4 :3-48.

McDonald, D. (1970).Fungal infection of groundnut fruits after after maturity and during drying.Trans.Brit. Mycol.54:461-472. 
Agric. Biol. J. N. Am., 2011, 2(4): 598-602

Pursglove, J.W. (1984)Tropical Crops Dicotyledons.John Wiley New York. Vol. 2791pp.

Shewfelt, A.L. and Young, C.T. (19770.storage stability of peanut based foods. Journal of Food Science 42:1148-1152.

Sullivan, G.A. (1984)Seed and Seedling Diseases In: Compendium of Peanut Diseases. Porter, D.M, Smith, D.H. and Rodriguez, K. (Eds.) pp37- 38., St Paul Minesota, U. S. American Phytopathological Society.Toxic Black Mold Information Centre (TBMIC)(2006) Common Species of Mold. Div. of Indoor Health Products, Inc.334 North Marshall Way, Suite C Layton, UT 84041.http://www.toxic-black-moldinfo.com/moldtypes.htm.

The U. S Government's Occupational Safety and Health Administration(OSHA) (2005) Microscopic Toxic Black Mold Photos. htt://www.pctureoftoxicmold.com

The U. S Government's Occupational Safety and Health Administration(OSHA) (2005)Mucor

mold.http://www.mould.ph/mucor-mould.htm

Turner,P.C., More, S.E. Hall., A.J., Prentice, A.M., and Wild, C.P. (2003) Modification of immune function through exposure to dietary aflatoxins in Gambian children. Environmental Health Perspectives.111:217220.

Umechuruba, C.I (1986). Longevity and Pathogenicity of fungi isolated from groundnut (Arachis hypogaea $\mathrm{L}$ ) seed lots from Nigeria stored at $5{ }^{\circ} \mathrm{C}$

Woodroof, J. G. (1984). Peanuts: Production, Processing, Products $3^{\text {rd }}$ West Port Connecticut Publishing. 895 pp. 